\title{
Genetic polymorphism in the adiponectin $(A D I P O Q)$ gene and its association with the production and reproduction traits of Indian dairy cattle
}

\author{
Vijay Pandey ${ }^{*}$, Rajesh Nigam¹, Satyendra P. Singh², Deepak Sharma ${ }^{2}$, Madhu Tiwari², \\ and Satish K. Garg ${ }^{3}$ \\ ${ }^{1}$ Department of Biochemistry, College of Veterinary Science and Animal Husbandry, DUVASU, Mathura, India \\ ${ }^{2}$ Department of Animal Genetics and Breeding, College of Veterinary Science and Animal Husbandry, DUVASU, \\ Mathura, India \\ ${ }^{3}$ Department of Pharmacology and Toxicology, College of Veterinary Science and Animal Husbandry, DUVASU, \\ Mathura, India
}

PANDEY, V., R. NIGAM, S. P. SINGH, D. SHARMA, M. TIWARI, S. K. GARG: Genetic polymorphism in the adiponectin $(A D I P O Q)$ gene and its association with the production and reproduction traits of Indian dairy cattle. Vet. arhiv 90, 19-26, 2020.

\section{ABSTRACT}

The present investigation was performed to explore the SNP in the promoter of the adiponectin $(A D I P O Q)$ gene and its association with production and reproduction traits in Indian Sahiwal cows. A portion of the promoter (ADIPOQ) region of the $A D I P O Q$ gene was amplified which revealed a $977 \mathrm{bp}$ amplicon, and its PCR-RFLP assay with the restriction enzyme TasI revealed three genotypes, in which the CT genotype was the most frequent $(62.32 \%)$, followed by CC (24.64\%) and TT (13.04\%). The frequency of the C and T alleles was 0.558 and 0.442 , respectively. The $A D I P O Q /$ TasI genotypes revealed a significant association with calving interval (CI) in the first and fourth lactations, in which the CC genotype showed a significantly $(\mathrm{P}<0.05)$ longer $\mathrm{CI}$ compared to the TT genotype, while in the fourth lactation the TT genotype showed a longer CI compared to the CC genotype. In the fourth lactation, the TT genotype showed a significantly $(\mathrm{P}<0.05)$ longer lactation period $(\mathrm{LP})$ and greater total milk yield $(\mathrm{TMY})$ as compared to CC and CT genotypes. In conclusion, the SNP identified in the promoter of the $A D I P O Q$ gene and its association with production and reproduction traits suggests that this gene might serve as a candidate genetic marker for selection of dairy cattle with better milk yield. However, further studies are needed to explore these SNPs in other regions of this gene, and in other breeds and populations.

Key words: $A D I P O Q$ gene; PCR-RFLP; SNP; reproduction traits; production traits; cattle

\section{Introduction}

Adiponectin is one of the most ample adipokines in the circulation that shows a negative correlation with fat mass (KADOWAKI and YAMAUCHI, 2005) and is reported to play important role in the regulation of fatty acid oxidation, glucose metabolism, insulin sensitivity, immunity, and reproduction (WAKI et al., 2003; BROCHUGAUDREAU et al., 2010). The natural expression patterns of adiponectin and their receptors in follicular and luteal cells of bovine ovary have also

\footnotetext{
*Corresponding author:

Dr. Vijay Pandey, Department of Veterinary Biochemistry, College of Veterinary Science and Animal Husbandry, UP Pandit Deen Dayal Upadhyaya Pashu Chikitsa Vigyan Vishwavidayala evam Go Anusandhan Sansthan, (DUVASU), Mathura, 281001, Uttar Pradesh, India, Phone: +91 9412777 945; E-mail: drvijaypandey@gmail.com
} 
been reported to affect the physiological status of the ovary (TABANDEH et al., 2010; MAILLARD et al., 2011). The information, regarding the role of adiponectin in energy metabolism and ovarian function, suggests that adiponectin could affect production and reproduction in dairy animals. Furthermore, the $A D I P O Q$ gene has been found to be located within the bovine chromosome (BTA) 1 region, which was previously reported to harbor QTL (KIM et al., 2010) that affects carcass traits in crossbred cattle. Moreover, several single nucleotide polymorphisms (SNPs) have been identified in the promoter, intron and $3^{\prime}$ UTR (untranslated region) regions of the $A D I P O Q$ gene and have revealed a significant association with meat quality traits in various breeds of beef cattle (CASAS et al., 2000; DAVIS et al., 1998; LI et al., 2004; MORSCI et al., 2006; ZHANG et al., 2009). Since genetic variability in the $A D I P O Q$ gene was found to play a role in the phenotypic expression of carcass traits in animals, it was hypothesized that genetic variability in this gene may also play a role in the phenotypic expression of the production and reproduction traits of dairy cows. Most research into genetic polymorphism in the $A D I P O Q$ gene has been conducted regarding their association with carcass traits in cattle, and no study related to their association with the production and reproduction traits of cattle has yet been undertaken. Thus, the present study was designed to explore the influence of genetic polymorphisms in the ADIPOQ gene and their possible association with production and reproduction traits in Sahiwal cows.

\section{Materials and methods}

Sampling and DNA extraction. Seventy Sahiwal cattle, maintained at the Instructional Livestock Farm Complex (ILFC) of the College of Veterinary Science and Animal Husbandry, Mathura, were used for the study. Approximately 5 mLof blood was collected from the jugular vein in vacutainer tubes containing EDTA as an anticoagulant, and genomic DNA was isolated as per the standard phenolchloroform isolation protocol (SAMBROOK and RUSSELL, 2001). The quality and quantity of DNA was determined using a spectrophotometer, by measuring the optical density ratio at a wavelength of 260 and $280 \mathrm{~nm}$.

PCR amplification. The following primer set (Table 1) was used to amplify the genomic sequence of the promoter region, based on the genomic sequence of the bovine ADIPOQ gene from GenBank Accession No. AH015166.2.

A total of $100-150 \mathrm{ng}$ of template DNA was amplified in a total volume of $25 \mu \mathrm{L}$ PCR mix in the thermocycler (Bio-Rad, USA). The PCR mix contained: $2.5 \mu \mathrm{L}$ PCR dream buffer $10 \mathrm{X}, 2.5 \mu \mathrm{L}$ of $2 \mathrm{mM}$ dNTPs, $0.5 \mathrm{pM}$ from each primer and 1 $\mathrm{U}$ Taq DNA polymerase. The thermal cycling was standardized at $94{ }^{\circ} \mathrm{C}$ for $5 \mathrm{~min}$ for initial denaturation, followed by 35 cycles of denaturation at $94{ }^{\circ} \mathrm{C}$ for $30 \mathrm{~s}$, annealing at $57.5^{\circ} \mathrm{C}$ for $30 \mathrm{~s}$ and extension at $72{ }^{\circ} \mathrm{C}$ for $1 \mathrm{~min}$. The final extension step was carried out for $5 \mathrm{~min}$ at $72^{\circ} \mathrm{C}$.

PCR-RFLP of ADIPOQ gene. Genotype analyses of $A D I P O Q$ gene was carried out using the polymerase chain reaction-restriction fragment length polymorphism (PCR-RFLP) method. For this, the PCR product of the $A D I P O Q$ gene was digested using Fast Digest TasI (Thermo Scientific) at $65{ }^{\circ} \mathrm{C}$ for 5 minutes in a hot water bath. The digestion reaction contained $10 \mu \mathrm{L}$ PCR product, $1 \mu \mathrm{L}$ of $10 \mathrm{X}$ Buffer, $0.5 \mu \mathrm{L}$ restriction enzyme and $8.5 \mu \mathrm{L}$ de-ionized water. The fragments were separated by horizontal gel electrophoresis in $2 \%$ agarose gel stained with ethidium bromide $(1 \mu \mathrm{g} /$ $\mu \mathrm{L}$ ) and electrophoresed in $1 \mathrm{X}$ TBE buffer prior to visualization under UV light.

Table 1. Primer set used for amplification of the $A D I P O Q$ gene

\begin{tabular}{|l|l|l|l|}
\hline Gene & Primer sequence & Region & Reference \\
\hline ADIPOQ & $\begin{array}{l}\text { F:5'-TTGTGTCTTCTGTATTGGCA-3' } \\
\text { R:5'-ACTGGACAAAATTCAGGATG-3' }\end{array}$ & $\begin{array}{l}\text { Promoter } \\
\text { (AH015166.2) }\end{array}$ & SHIN and CHUNG, 2013 \\
\hline
\end{tabular}


Statistical analysis. The allelic and genotypic frequencies (FALCONER and MACKAY, 1996) of the $A D I P O Q / T a s I$ polymorphism was examined for deviation from the Hardy-Weinberg equilibrium using the $\chi 2$ test (SNEDECOR and COCHRAN, 1989), and statistical significance was determined by the ANOVA test, followed by Tukey's post-hoc multiple comparison tests using SPSS software for Windows (version 16.0). The data were presented as the mean \pm SEM and a P-value $<0.05$ was considered to be statistically significant.

\section{Results}

ADIPOQ/TsaI PCR-RFLP assay. The amplification of the $A D I P O Q$ gene revealed a 977 bp amplicon which was observed on $1.0 \%$ agarose gel (Fig. 1).

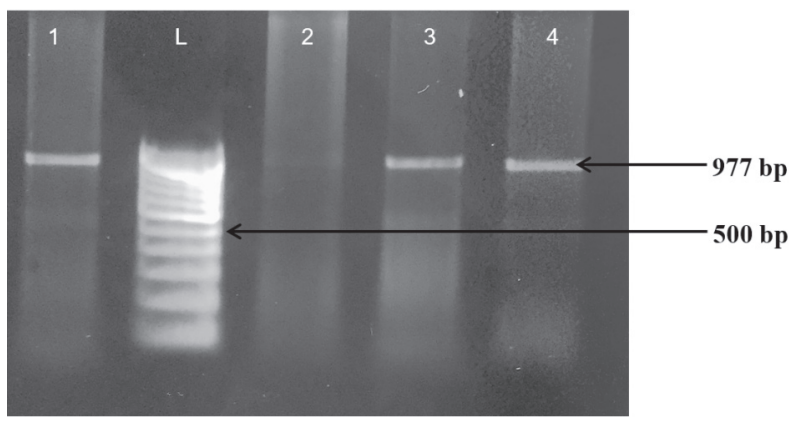

Fig. 1. Agarose gel electrophoresis (1\%) of the $A D I P O Q$ PCR product showing $977 \mathrm{bp}$ amplicons in all lanes (1-4), L= Ladder (100bp).
The TasI/PCR-RFLP assay revealed three types of banding patterns (genotypes); one of them was the CC genotype, the second was the TT genotype and the third was the CT genotype (Fig. 2). The amplicon of the CC genotype had 4 restriction sites and thus revealed 5 fragments of $607,243,96,18$ and $13 \mathrm{bp}$. The amplicon of the TT genotype had 5 restriction sites that revealed six fragments of 454 , 243, 153, 96, 18 and $13 \mathrm{bp}$. The amplicon of the CT genotype showed all seven fragments of 607, 454, 243, 153, 96, 18 and 13 bp. For the PCR-RFLP assay, the important fragment was the fragment of $607 \mathrm{bp}$ which showed mutation in the sequence. The CC genotype showed an intact fragment of 607 $\mathrm{bp}$, while the TT genotype revealed a restriction site and showed two fragments of 454 and 153, and thus the CT genotype showed all these three fragments (607, 454 and 153). Other fragments were common in all three genotypes. The results revealed that the population studied of Sahiwal cattle was polymorphic in nature, with two types of alleles, $\mathrm{C}$ and $\mathrm{T}$, with three types of genotypes: $\mathrm{CC}$ genotype, TT genotype and CT genotype, in the screened samples.

Further, the presence of the restriction sites for TasI in the PCR amplified ADIPOQ gene was confirmed by DNA sequencing. The sequence of ADIPOQ/TasI obtained after alignment revealed $\mathrm{C} \rightarrow \mathrm{T}$ substitution at nucleotide position $1431 \mathrm{C}>\mathrm{T}$. For the $\mathrm{CC}$ genotype, no $\mathrm{C} \rightarrow \mathrm{T}$ substitution was

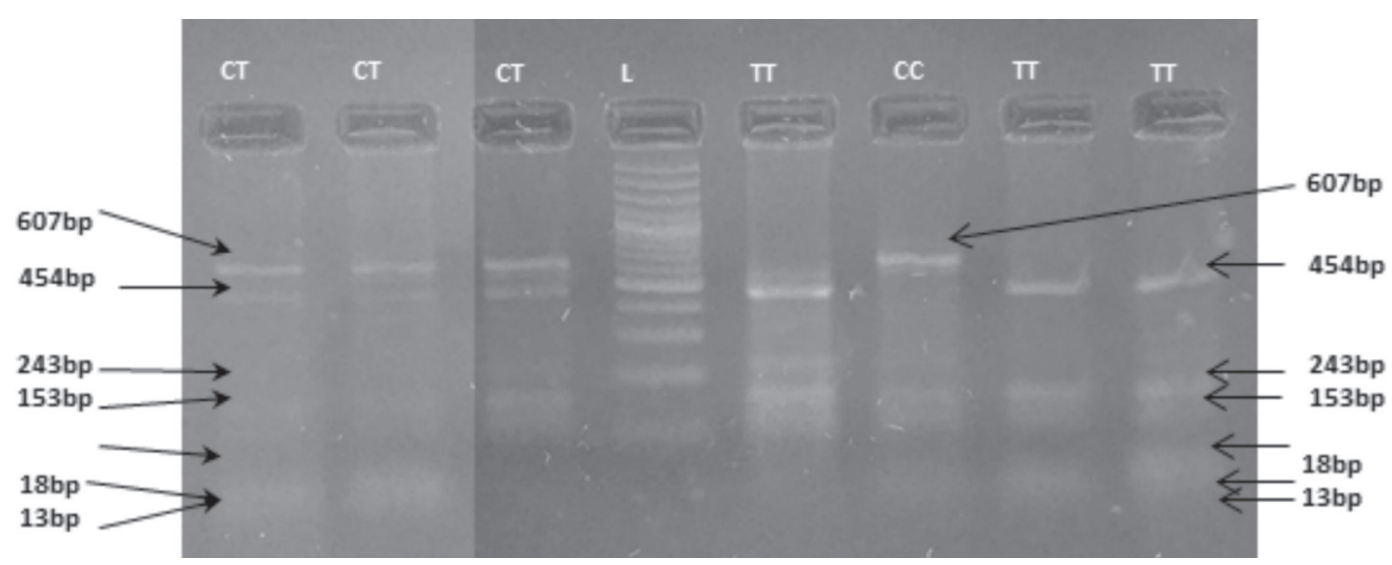

Fig. 2. ADIPOQ/TasI PCR-RFLP assay showing genotype pattern in 2.0\% agarose gel; Lane 1-2: TT genotype (454, 243, 153, 96, 18 \& 13); Lane 3: CC genotype (607, 243, 96, 18 \& 13); Lane 4, 6-8: CT genotype (607, 454, 243, 153, 96, 18 \& 13); Lane 5: Ladder (100 bp) 
found, for the $\mathrm{CT}$ genotype $\mathrm{C} \rightarrow \mathrm{T}$ substitution was found in only one strand, for the TT genotype $\mathrm{C} \rightarrow \mathrm{T}$ substitution was found in both strands (Fig. 3).

The results of this study revealed that the CT genotype was the most frequent $(62.32 \%)$ in all the screened samples, followed by the CC genotype (24.64\%), whereas the TT genotype was least frequent in these samples $(13.04 \%)$. The frequency of the $\mathrm{C}$ and $\mathrm{T}$ alleles of $A D I P O Q /$ Tas I was 0.558 and 0.442 , respectively. The $\chi 2$ calculated value for the $A D I P O Q / T a s$ I gene was 27.48 , while $\chi 2$ table values were 3.84 and 6.64 at $5 \%$ and $1 \%$ level of significance, respectively for the degrees of freedom 1 . These results revealed that $\chi^{2}(\mathrm{cal})>\chi^{2}$ (tab) at $1 \%$ level of significance, which indicates that the selected population of Sahiwal cattle was not in Hardy-Weinberg equilibrium (Table 2).
Association of $A D I P O Q / T a s$ I genotypes with production and reproduction traits. The means with standard errors (Mean $\pm \mathrm{SEM}$ ) for each trait related to each genotype for four lactations are given in Tables 3 and 4, respectively. The association study of the ADIPOQ/TasI PCR-RFLP assay revealed the significant influence of genotypes on calving interval (CI), lactation period (LP), total milk yield (TMY) and days to reach peak yield (DRPY). The genetic polymorphism of ADIPOQ/ TasI revealed a significant effect on LP, and TMY in the fourth lactation in the TT genotype showed significantly higher values compared to the CC and CT genotypes. The DRPY of cows showed a significant association with genotypes in the second lactation, which revealed higher values for the CT genotype compared to the TT genotype.
(A)

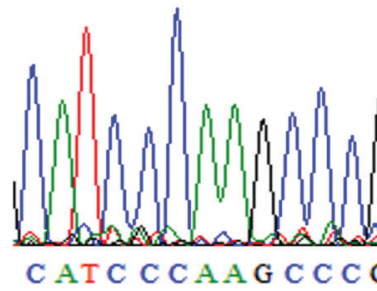

(B)

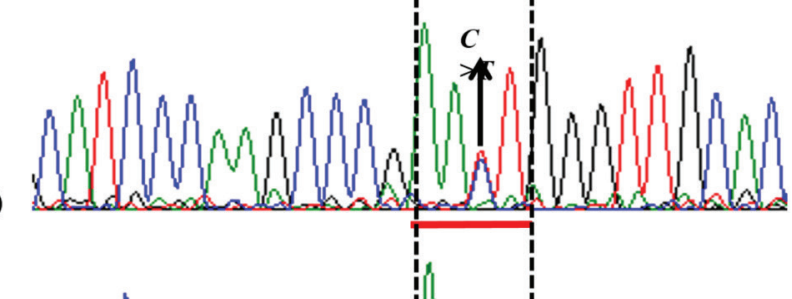

(C)

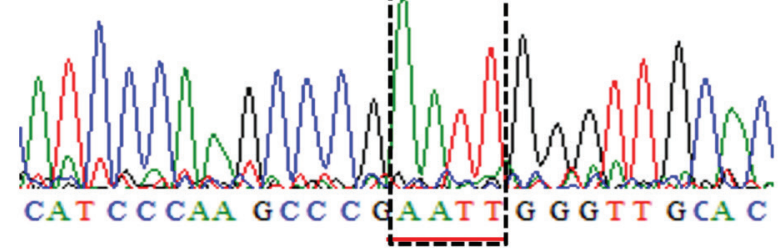

CC Genotype

CT Genotype

\section{TT Genotype}

Fig. 3. Chromatograms of ADPOQ gene sequence showing $\mathrm{C}>\mathrm{T}$ nucleotide substitution in the promoter region. (A) CC genotype (B) CT genotype (C) TT genotype

Table 2. Genotypic and allelic frequencies of $\mathrm{C}>T$ SNP/TasI genotypes in Sahiwal

\begin{tabular}{|c|c|c|c|c|c|c|}
\hline \multirow[b]{2}{*}{ Breed } & \multicolumn{3}{|c|}{ Genotypic frequency (\%) } & \multicolumn{2}{|c|}{ Allelic Frequency } & \multirow[b]{2}{*}{$\chi 2$ test } \\
\hline & $\mathrm{CC}$ & $\mathrm{CT}$ & $\mathrm{TT}$ & $\mathrm{G}$ & $\mathrm{T}$ & \\
\hline $\begin{array}{l}\text { Sahiwal } \\
(\mathrm{n}=69)\end{array}$ & $\begin{array}{c}24.64 \\
(\mathrm{n}=17)\end{array}$ & $\begin{array}{c}62.32 \\
(n=43)\end{array}$ & $\begin{array}{c}13.04 \\
(\mathrm{n}=09)\end{array}$ & 0.558 & 0.442 & $\begin{array}{c}\chi^{2} \mathrm{cal}=27.48 \\
\chi^{2} \mathrm{tab}=6.64(\mathrm{P}<0.01) \\
\chi^{2} \mathrm{cal}>\chi^{2} \mathrm{tab}\end{array}$ \\
\hline
\end{tabular}


The CI of cows showed a significant association with genotypes in the first and fourth lactations. The CC genotype showed a significantly longer CI compared to the TT genotype, while in the fourth lactation the TT genotype showed a significantly longer CI compared to the $\mathrm{CC}$ genotype.

\section{Discussion}

Genetic polymorphism of the $A D I P O Q$ gene $(1431 \mathrm{C}>\mathrm{T})$ has not been widely studied in cattle breeds and most studies have been conducted in beef cattle regarding their carcass traits. This is the first study conducted so far to elucidate the effects of genetic polymorphism in the $A D I P O Q$ gene on the production and reproduction traits of dairy cattle.
In the present investigation, the $A D I P O Q /$ TasI assay revealed three genotypes. SHIN and CHUNG (2013) also found similar observations in the Hanwoo (Korean) cattle population, and revealed three genotypes, where CT had the highest genotypic frequency $(68.9 \%)$, followed by TT $(16.0 \%)$ and CC (15.1\%) genotypes, with deviations from Hardy-Weinberg equilibrium in the studied population. These findings of genotypic frequency reported by SHIN and CHUNG (2013) corroborate well with the results of the present study. Furthermore, they reported the allelic frequency of $\mathrm{C}$ and $\mathrm{T}$ alleles as 49.6 and 50.4, respectively, which is also comparable with the findings of our present study. In contrast, MORSCI et al. (2006) also reported $A D I P O Q / T a s I$ polymorphism in Angus

Table 3. Association of $A D I P O Q / T a s I$ genotypes with reproduction traits

\begin{tabular}{|c|c|c|c|c|c|c|c|c|}
\hline Lactation & Genotype & $\mathrm{n}$ & $\begin{array}{l}\text { BW } \\
(\mathrm{kg})\end{array}$ & $\begin{array}{c}\text { AFS } \\
\text { (days) }\end{array}$ & $\begin{array}{c}\mathrm{AFC} \\
\text { (days) }\end{array}$ & $\begin{array}{c}\text { GP } \\
\text { (days) }\end{array}$ & $\begin{array}{c}\text { DP } \\
\text { (days) }\end{array}$ & $\begin{array}{c}\mathrm{CI} \\
\text { (days) }\end{array}$ \\
\hline \multirow{3}{*}{$\begin{array}{c}\mathrm{I} \\
(\mathrm{n}=55)\end{array}$} & $\mathrm{CC}$ & 12 & $\begin{array}{l}20.75 \\
\pm 3.75 \\
\end{array}$ & $\begin{array}{l}986.00 \\
\pm \mathbf{5 4 . 0 0} \\
\end{array}$ & $\begin{array}{l}1547.00 \\
\pm \mathbf{2 0 1 . 0 0} \\
\end{array}$ & $\begin{array}{r}281.50 \\
\pm \mathbf{3 . 5 0} \\
\end{array}$ & $\begin{array}{l}223.83 \\
\pm 37.43 \\
\end{array}$ & $\begin{array}{l}639.25^{\mathrm{a}} \\
\pm 49.17 \\
\end{array}$ \\
\hline & CT & 36 & $\begin{array}{l}20.43 \\
\pm 0.65\end{array}$ & $\begin{array}{c}1077.90 \pm \\
72.36\end{array}$ & $\begin{array}{r}1587.38 \\
\pm \mathbf{6 3 . 6 1}\end{array}$ & $\begin{array}{r}278.33 \\
\pm \mathbf{2 . 7 1}\end{array}$ & $\begin{array}{l}175.97 \\
\pm 17.43\end{array}$ & $\begin{array}{r}554.92^{\mathrm{ab}} \\
\pm 23.52\end{array}$ \\
\hline & TT & 7 & $\begin{array}{l}19.88 \\
\pm \mathbf{0 . 9 7}\end{array}$ & $\begin{array}{c}1306.00 \\
\pm \mathbf{1 1 0 . 1 0}\end{array}$ & $\begin{array}{r}1759.25 \\
\pm \mathbf{6 2 . 8 0}\end{array}$ & $\begin{array}{r}284.25 \\
\pm \mathbf{2 . 5 6}\end{array}$ & $\begin{array}{l}141.71 \\
\pm 35.55\end{array}$ & $\begin{array}{l}502.00^{\mathrm{b}} \\
\pm 39.15\end{array}$ \\
\hline \multirow{3}{*}{$\begin{array}{c}\text { II } \\
(\mathrm{n}=40)\end{array}$} & $\mathrm{CC}$ & 10 & & & & $\begin{array}{r}278.20 \\
\pm 3.37\end{array}$ & $\begin{array}{l}117.20 \\
\pm 21.12\end{array}$ & $\begin{array}{l}475.20 \\
\pm 31.40\end{array}$ \\
\hline & CT & 25 & & & & $\begin{array}{r}284.96 \\
\pm 1.94 \\
\end{array}$ & $\begin{array}{l}117.20 \\
\pm 15.22 \\
\end{array}$ & $\begin{array}{l}510.60 \\
\pm 23.59 \\
\end{array}$ \\
\hline & $\mathrm{TT}$ & 5 & & & & $\begin{array}{r}286.40 \\
\pm 2.84\end{array}$ & $\begin{array}{l}131.80 \\
\pm 66.55\end{array}$ & $\begin{array}{l}492.80 \\
\pm 62.30\end{array}$ \\
\hline \multirow{3}{*}{$\begin{array}{c}\text { III } \\
(\mathrm{n}=24)\end{array}$} & $\mathrm{CC}$ & 4 & & & & $\begin{array}{r}289.50 \\
\pm 8.26\end{array}$ & $\begin{array}{l}162.00 \\
\pm 38.70\end{array}$ & $\begin{array}{l}527.75 \\
\pm 33.08\end{array}$ \\
\hline & $\mathrm{CT}$ & 17 & & & & $\begin{array}{r}282.18 \\
\pm 1.35 \\
\end{array}$ & $\begin{array}{l}144.59 \\
\pm 19.10 \\
\end{array}$ & $\begin{array}{l}480.00 \\
\pm 22.93 \\
\end{array}$ \\
\hline & $\mathrm{TT}$ & 3 & & & & $\begin{array}{r}288.67 \\
\pm 2.73\end{array}$ & $\begin{array}{c}99.67 \\
\pm 29.24\end{array}$ & $\begin{array}{l}457.00 \\
\pm 40.61\end{array}$ \\
\hline \multirow{3}{*}{$\begin{array}{c}\text { IV } \\
(\mathrm{n}=22)\end{array}$} & $\mathrm{CC}$ & 3 & & & & $\begin{array}{r}286.40 \\
\pm 3.12\end{array}$ & $\begin{array}{l}115.80 \\
\pm 27.74\end{array}$ & $\begin{array}{l}431.20^{\mathrm{a}} \\
\pm 43.28\end{array}$ \\
\hline & $\mathrm{CT}$ & 12 & & & & $\begin{array}{r}280.07 \\
\pm 2.12 \\
\end{array}$ & $\begin{array}{l}143.86 \\
\pm 26.40 \\
\end{array}$ & $\begin{array}{r}448.14^{\mathrm{ab}} \\
\pm 23.46\end{array}$ \\
\hline & $\mathrm{TT}$ & 7 & & & & $\begin{array}{r}281.67 \\
\pm 4.41\end{array}$ & $\begin{array}{l}134.67 \\
\pm 52.84\end{array}$ & $\begin{array}{c}562.67^{\mathrm{b}} \\
\pm 60.86\end{array}$ \\
\hline
\end{tabular}

${ }^{\text {abc }}$ Means bearing a same superscript in a column for one lactation differ non-significantly $(\mathrm{P}>0.05)$; BW - Birth weight; AFS - Age at first service; AFC - Age at first calving; GP - Gestation period; DP - Dry period; CI - Calving interval 
Table 4. Association of $A D I P O Q / T a s I$ genotypes with milk production traits.

\begin{tabular}{|c|c|c|c|c|c|c|c|c|c|}
\hline Lactation & Genotype & $\mathrm{n}$ & $\begin{array}{c}\text { LP } \\
\text { (days) }\end{array}$ & $\begin{array}{c}\text { TMY } \\
\text { (liters) }\end{array}$ & $\begin{array}{l}\text { AMY } \\
\text { (liters) }\end{array}$ & $\begin{array}{l}\text { MYPP } \\
\text { (liters) }\end{array}$ & $\begin{array}{c}\text { MY300 } \\
\text { (liters) }\end{array}$ & $\begin{array}{c}\text { PY } \\
\text { (liters/day) }\end{array}$ & $\begin{array}{l}\text { DRPY } \\
\text { (days) }\end{array}$ \\
\hline \multirow{3}{*}{$\begin{array}{c}\mathrm{I} \\
(\mathrm{n}=55)\end{array}$} & $\mathrm{CC}$ & 12 & $\begin{array}{l}422.50 \\
\pm 36.98\end{array}$ & $\begin{array}{l}2049.00 \\
\pm 258.64\end{array}$ & $\begin{array}{c}4.83 \\
\pm 0.31\end{array}$ & $\begin{array}{l}72.92 \\
\pm 9.42\end{array}$ & $\begin{array}{r}1449.33 \\
\pm 92.13\end{array}$ & $\begin{array}{l}7.04 \\
\pm 0.51\end{array}$ & $\begin{array}{l}41.08 \\
\pm 3.40\end{array}$ \\
\hline & $\mathrm{CT}$ & 36 & $\begin{array}{l}379.22 \\
\pm 18.58 \\
\end{array}$ & $\begin{array}{l}1918.53 \\
\pm 140.74 \\
\end{array}$ & $\begin{array}{c}4.92 \\
\pm 0.17 \\
\end{array}$ & $\begin{array}{l}79.28 \\
\pm 4.53 \\
\end{array}$ & $\begin{array}{r}1477.39 \\
\pm 51.28 \\
\end{array}$ & $\begin{array}{c}7.53 \\
\pm 0.29 \\
\end{array}$ & $\begin{array}{l}42.31 \\
\pm 3.08 \\
\end{array}$ \\
\hline & TT & 7 & $\begin{array}{l}375.43 \\
\pm 29.35\end{array}$ & $\begin{array}{r}2024.00 \\
\pm 78.08 \\
\end{array}$ & $\begin{array}{c}5.50 \\
\pm 0.34 \\
\end{array}$ & $\begin{array}{l}80.14 \\
\pm 7.16\end{array}$ & $\begin{array}{l}1657.00 \\
\pm 102.23 \\
\end{array}$ & $\begin{array}{c}8.14 \\
\pm 0.60 \\
\end{array}$ & $\begin{array}{l}46.57 \\
\pm 5.94 \\
\end{array}$ \\
\hline \multirow{3}{*}{$\begin{array}{c}\text { II } \\
(n=40)\end{array}$} & $\mathrm{CC}$ & 10 & $\begin{array}{l}368.50 \\
\pm 38.55 \\
\end{array}$ & $\begin{array}{l}2120.80 \\
\pm 217.85 \\
\end{array}$ & $\begin{array}{c}5.94 \\
\pm 0.58 \\
\end{array}$ & $\begin{array}{l}110.05 \\
\pm 8.60 \\
\end{array}$ & $\begin{array}{l}1784.80 \\
\pm 174.16 \\
\end{array}$ & $\begin{array}{c}8.15 \\
\pm 0.53 \\
\end{array}$ & $\begin{array}{r}39.00^{\mathrm{ab}} \\
\pm 5.42 \\
\end{array}$ \\
\hline & $\mathrm{CT}$ & 25 & $\begin{array}{l}390.84 \\
\pm 15.46 \\
\end{array}$ & $\begin{array}{l}2248.60 \\
\pm 123.62 \\
\end{array}$ & $\begin{array}{c}5.72 \\
\pm 0.21\end{array}$ & $\begin{array}{r}109.28 \\
\pm 6.52 \\
\end{array}$ & $\begin{array}{l}1717.56 \\
\pm 63.10 \\
\end{array}$ & $\begin{array}{c}9.12 \\
\pm 0.45\end{array}$ & $\begin{array}{l}42.92^{\mathrm{b}} \\
\pm 2.43\end{array}$ \\
\hline & TT & 5 & $\begin{array}{l}360.00 \\
\pm 44.55 \\
\end{array}$ & $\begin{array}{l}2273.00 \\
\pm 274.61 \\
\end{array}$ & $\begin{array}{c}6.36 \\
\pm 0.44 \\
\end{array}$ & $\begin{array}{l}124.80 \\
\pm 13.85 \\
\end{array}$ & $\begin{array}{l}1909.80 \\
\pm 136.33 \\
\end{array}$ & $\begin{array}{l}9.90 \\
\pm 0.76 \\
\end{array}$ & $\begin{array}{l}29.00^{\mathrm{a}} \\
\pm 2.14 \\
\end{array}$ \\
\hline \multirow{3}{*}{$\begin{array}{c}\text { III } \\
(n=24)\end{array}$} & $\mathrm{CC}$ & 4 & $\begin{array}{l}380.50 \\
\pm 28.66\end{array}$ & $\begin{array}{r}1904.50 \\
\pm 59.86\end{array}$ & $\begin{array}{c}4.95 \\
\pm 0.35\end{array}$ & $\begin{array}{l}89.00 \\
\pm 0.80 \\
\end{array}$ & $\begin{array}{l}1483.50 \\
\pm 109.10\end{array}$ & $\begin{array}{c}8.25 \\
\pm 0.43\end{array}$ & $\begin{array}{l}40.75 \\
\pm 5.01\end{array}$ \\
\hline & $\mathrm{CT}$ & 17 & $\begin{array}{l}347.12 \\
\pm 23.53 \\
\end{array}$ & $\begin{array}{r}2092.94 \\
\pm 94.47 \\
\end{array}$ & $\begin{array}{c}5.91 \\
\pm 0.35 \\
\end{array}$ & $\begin{array}{l}104.68 \\
\pm 11.79 \\
\end{array}$ & $\begin{array}{l}1774.53 \\
\pm 104.04\end{array}$ & $\begin{array}{c}9.56 \\
\pm 0.59\end{array}$ & $\begin{array}{l}41.00 \\
\pm 3.16 \\
\end{array}$ \\
\hline & TT & 3 & $\begin{array}{l}359.33 \\
\pm 22.48 \\
\end{array}$ & $\begin{array}{c}2248.33 \\
\pm 4.22\end{array}$ & $\begin{array}{c}6.27 \\
\pm 0.22\end{array}$ & $\begin{array}{r}131.33 \\
\pm 3.86 \\
\end{array}$ & $\begin{array}{r}1885.00 \\
\pm 69.18\end{array}$ & $\begin{array}{l}10.50 \\
\pm 0.58\end{array}$ & $\begin{array}{l}31.33 \\
\pm 6.17\end{array}$ \\
\hline \multirow{3}{*}{$\begin{array}{c}\text { IV } \\
(n=22)\end{array}$} & $\mathrm{CC}$ & 3 & $\begin{array}{l}314.80^{\mathrm{a}} \\
\pm 23.15 \\
\end{array}$ & $\begin{array}{l}1526.20^{\mathrm{a}} \\
\pm 110.73 \\
\end{array}$ & $\begin{array}{c}4.88 \\
\pm 0.31 \\
\end{array}$ & $\begin{array}{l}89.40 \\
\pm 8.50 \\
\end{array}$ & $\begin{array}{l}1464.80 \\
\pm 90.96 \\
\end{array}$ & $\begin{array}{l}7.90 \\
\pm 0.71 \\
\end{array}$ & $\begin{array}{c}60.40 \\
\pm 19.48 \\
\end{array}$ \\
\hline & $\mathrm{CT}$ & 12 & $\begin{array}{l}302.86^{\mathrm{a}} \\
\pm 14.67 \\
\end{array}$ & $\begin{array}{r}1826.86^{\mathrm{a}} \\
\pm 158.92 \\
\end{array}$ & $\begin{array}{c}5.92 \\
\pm 0.44 \\
\end{array}$ & $\begin{array}{l}92.79 \\
\pm 9.96 \\
\end{array}$ & $\begin{array}{l}1780.36 \\
\pm 130.10 \\
\end{array}$ & $\begin{array}{c}9.36 \\
\pm 0.77 \\
\end{array}$ & $\begin{array}{l}45.00 \\
\pm 4.76 \\
\end{array}$ \\
\hline & TT & 7 & $\begin{array}{l}433.33^{\mathrm{b}} \\
\pm 91.84\end{array}$ & $\begin{array}{l}2658.67^{\mathrm{b}} \\
\pm 201.33\end{array}$ & $\begin{array}{c}6.57 \\
\pm 1.20\end{array}$ & $\begin{array}{l}128.00 \\
\pm 24.58\end{array}$ & $\begin{array}{l}1970.67 \\
\pm 358.29\end{array}$ & $\begin{array}{l}10.17 \\
\pm 2.03\end{array}$ & $\begin{array}{l}38.00 \\
\pm 6.66\end{array}$ \\
\hline
\end{tabular}

${ }^{a b c}$ Means bearing a same superscript in a column for one lactation differ non-significantly $(\mathrm{P}>0.05)$

cattle and observed three genotypes, viz., major, minor and heterozygous genotypes, with genotypic frequencies of $65.86 \%, 3.57 \%$ and $30.57 \%$, respectively. The allele frequency was 0.81 for the major allele and 0.19 for the minor allele.

Association studies of CC, CT and TT genotypes of the $A D I P O Q$ gene by $A D I P O Q /$ TasI PCR-RFLP assay revealed the significant association of these genotypes with CI, LP, TMY and, DRPY. The CT and TT genotypes had longer CI in the first and fourth lactations, suggesting that the $\mathrm{T}$ allele has a significant effect on CI. Likewise, a longer LP was observed for the TT genotype compared to the CC and $\mathrm{CT}$ genotypes. In addition, TMY showed higher milk yield in the TT genotype compared to the CC and CT genotype. These results suggest that the $\mathrm{T}$ allele of the $A D I P O Q /$ TasI gene may be considered to be a good indicator of milk production in the Sahiwal cattle breed.

In the present study, $A D I P O Q /$ TasI SNPs in the promoter region of the gene revealed a significant association with the reproduction and production traits of Sahiwal cows. The promoter region of the $A D I P O Q$ gene contains several regulatory sequences which control the expression of the $A D I P O Q$ gene, and interact with a large number of cis-acting and trans-acting factors. Therefore, the activity and variations in the $A D I P O Q$ gene promoter region could regulate gene expression, and affect the metabolic pathways of fat and glucose metabolism. Many studies have shown that the $A D I P O Q$ transcript is predominantly 
expressed in the adipose tissues of human, rodents and porcine (DAI et al., 2006). It may suggest that bovine $A D I P O Q$ is likely to play an important role in lipid metabolism, such as fat differentiation and deposition in cattle as in other species (SHIN and CHUNG, 2013).

This was the first report to investigate the association of genetic polymorphism in the $A D I P O Q$ gene on the production and reproduction traits of Sahiwal dairy cattle. Most earlier studies conducted of genetic polymorphism in the $A D I P O Q$ gene investigated their association with carcass traits in beef cattle (MORSCI et al., 2006; SHIN and CHUNG, 2013). Thus, due to the paucity of the available literature, the results could not be discussed further.

In conclusion, the SNP identified in the $A D I P O Q$ gene and its association with production and reproduction traits suggests that this gene might serve as a candidate genetic marker for selection of dairy cattle with better milk yield. However, further studies are needed to validate this SNP of the ADIPOQ gene in other breeds and populations of dairy cattle, and its association with other production and reproduction traits need to be verified.

\section{References}

BROCHU-GAUDREAU, K., C. REHFELDT, R. BLOUIN, V. BORDIGNON, B. D. MURPHY, M. F. PALIN (2010): Adiponectin action from head to toe. Endocrinology 37, 11-32.

DOI: $10.1007 / \mathrm{s} 12020-009-9278-8$

CASAS, E., S. D. SHACKELFORD, J. W. KEELE, R. T. STONE, S. M. KAPPES, M. KOOHMARAIE (2000): Quantitative trait loci affect growth and carcass composition of cattle segregating alternate forms of myostatin. J. Anim. Sci. 78, 560-569.

DOI: $10.2527 / 2000.783560 \mathrm{x}$

DAI, L. H., Y. Z. XIONG, C. Y. DENG, S. W. JIANG, B. ZUO, R. ZHENG, F. E. LI, M. C. LEI. (2006): Association of the $\mathrm{A}-\mathrm{G}$ polymorphism in porcine adiponectin gene with fat deposition and carcass traits. Asian-Australas. J. Anim. Sci. 19, 779-783.

DOI: $10.5713 /$ ajas.2006.779

DAVIS, G. P., D. J. S. HETZEL, N. J. CORBET, S. SCACHERI, S. LOWDEN, J. RENAUD, C. MAYNE, R. STEVENSON, S. S. MOORE, K. BYRNE (1998): The mapping of quantitative trait loci for birth weight in a tropical beef herd. Proceedings of the $6^{\text {th }}$ World Congress on Genetics Applied to Livestock Production. Armidale 26, pp. 441-444.

FALCONER, D. S., T. F. C. MACKAY (1996): In: Introduction to Quantitative Genetics. ${ }^{\text {th }}$ ed., Addison Wesley Longman Limited, England, p. 56.

KADOWAKI, T. T., T. YAMAUCHI (2005): Adiponectin and adiponectin receptors. Endocr. Rev. 26, 439-451.

DOI: 10.1210/er.2005-0005

KIM, J. B., D. J. KIM, J. K. LEE, C. Y. LEE (2010): Genetic relationship between carcass traits and carcass price of Korean cattle. Asian-Australas. J. Anim. Sci. 23, 848-854. DOI: 10.5713/ajas.2010.90555

LI, C., J. BASARAB, W. M. SNELLING, B. BENKEL, J. KNEELAND, B. MURDOCH, C. HANSEN, S. S. MOORE (2004): Identification and fine mapping of quantitative trait loci for backfat on bovine chromosomes 2, 5, 6, 19, 21, and 23 in a commercial line of Bos taurus. J. Anim. Sci. 82, 967-972.

DOI: $10.2527 / 2004.824967 \mathrm{x}$

MAILLARD, V., P. FROMENT, C. RAME, S. UZBEKOVA, S. ELIS, J. DUPONT (2011): Expression and effect of resistin on bovine and rat granulosa cell steroidogenesis and proliferation. Reproduction 141, 467-479.

DOI: $10.1530 /$ rep-10-0419

MORSCI, N. S., R. D. SCHNABEL, J. F. TAYLOR (2006): Association analysis of adiponectin and somatostatin polymorphisms on BTA1 with growth and carcass traits in Angus cattle. Anim. Genet. 37, 554-562.

DOI: $10.1111 /$ j.1365-2052.2006.01528.x

SAMBROOK, J., D. W. RUSSEL (2001): In: Molecular cloning: A laboratory Manual. Cold Spring Harbor Tab, Press, New York, pp. 6.4-6.11.

SHIN, S., E. CHUNG (2013): Novel SNPs in the bovine $A D I P O Q$ and PPARGC1A genes are associated with carcass traits in Hanwoo (Korean cattle). Mol. Biol. Rep. 40, 4651-4660.

DOI: $10.1007 / \mathrm{s} 11033-013-2560-0$

SNEDECOR, G. W., W. G. COCHRAN (1989). In: Statistical Methods. $8^{\text {th }}$ ed. Ames: Iowa State Press, USA.

TABANDEH, M. R., A. HOSSEINI, M. SAEB, M. KAFI, S. SAEB (2010): Changes in the gene expression of adiponectin and adiponectin receptors (AdipoR1 and AdipoR2) in ovarian follicular cells of dairy cow at different stages of development. Theriogenology 73, 659-669.

DOI: 10.1016/j.theriogenology.2009.11.006

WAKI, H., T. YAMAUCHI, J. KAMON, Y. ITO, S. UCHIDA, S. KITA (2003): Impaired multimerization of human adiponectin mutants associated with diabetes: Molecular structure and multimer formation of adiponectin. J. Biolog. Chemistry 278, 40352-40363.

DOI: $10.1074 /$ jbc.m300365200 
ZHANG, L., H. CHEN, X. LAN, C. ZHANG, L. ZHANG, A. ZHANG, Q. ZHANG, C. LEI, H. ZHANG (2009): The novel $5 \mathrm{bp}$ deletion polymorphism in the promoter region of bovine ACRP30 gene. Mol. Biol. Reprod. 36, 895-899.

DOI: $10.1007 / \mathrm{s} 11033-008-9260-1$
Received: 22 June 2018

Accepted: 9 October 2019

PANDEY, V., R. NIGAM, S. P. SINGH, D. SHARMA, M. TIWARI, S. K. GARG: Polimorfizam gena za adiponektin $(A D I P O Q)$ i njegova povezanost s proizvodnim i rasplodnim svojstvima indijskog mliječnog goveda. Vet. arhiv 90, 19-26, 2020.

\section{SAŽETAK}

Cilj ovoga rada bio je istražiti polimorfizam pojedinačnog nukleotida (SNP) u promotoru gena za adiponektin $(A D I P O Q)$ i njegovu povezanost s proizvodnim i rasplodnim svojstvima indijskog goveda Sahiwal pasmine. Dio promotora $(A D I P O Q)$ regije gena $A D I P O Q$ je umnožen i prikazan produktom $977 \mathrm{bp}$, a PCR-RFLP metodom s restrikcijom enzimom TasI dobivena su tri genotipa. Među njima najčešći je bio CT genotip (62,32\%), zatim CC $(24,64 \%)$ i TT $(13,04 \%)$. Učestalost C-alela bila je 0,558, a T-alela 0,442. ADIPOQ/TasI genotipovi su pokazali znakovitu povezanost s međutelidbenim intervalom (CI) u prvoj i četvrtoj laktaciji u kojima je CC genotip pokazao znakovito duži interval između teljenja $(\mathrm{P}<0,05)$ u usporedbi s TT genotipom, dok je u četvrtoj laktaciji TT genotip pokazao duži interval teljenja u usporedbi s CC genotipom. U četvrtoj laktaciji TT genotip pokazao je znakovito duže trajanje laktacije (LP) $(\mathrm{P}<0,05)$ i ukupan prinos mlijeka (TMY) u usporedbi s CC i CT genotipovima. Zaključno, SNP identificiran u promotoru gena $A D I P O Q$ i njegova povezanost s proizvodnim i reproduktivnim svojstvima upućuju na to da ovaj gen može poslužiti kao kandidatni genski biljeg za selekciju mliječnih krava s većim prinosom mlijeka. Potrebna su daljnja istraživanja polimorfizama pojedinačnih nukleotida u drugim regijama ovoga gena kao i u drugih pasmina i populacija.

Ključne riječi: gen $A D I P O Q$; PCR-RFLP; SNP; reproduktivna svojstva; proizvodna svojstva; govedo 